University, May 15-16, 1984

\title{
IMPROVING THE ENERGY PERFORMANCE OF RESIDENTIAL CLOTHES DRYERS
}

\author{
Dariusch Hekmat and William J. Fisk \\ Building Ventilation and Indoor Air Quality Program \\ Lawrence Berkeley Laboratory \\ University of California \\ Berkeley, California 94720
}

This work was supported by the Assistant Secretary for Conservation and Renewable Energy, Office of Building Energy Research and Development, Building Systems Division of the U.S. Department of Energy under Contract No. DE-AC03-76SF00098. 


\section{IMPROV ING THE ENERGY PERFORMANCE OF RESIDENTIAL CLOTHES DRYERS \\ Dariusch Hekmat and William J. Fisk \\ Applied Science Division \\ Lawrence Berkeley Laboratory \\ University of California \\ Berkeley, CA 94720}

\section{ABSTRACT}

Experiments were conducted to evaluate four techniques to 1mprove the energy efficlency of electrically-heated domestic clothes dryers. Reduced air flow rate and heater 1nput led to energy savings around $8 \%$, while recirculation of a portion of the exhaust a1r back into the clothes dryer reduced energy consumption by approximately 18\%. These two measures are attractive because of their low cost. Two modes of using an air-to-air heat exchanger for heat recovery were considered. The first is to preheat the inlet air with heat from the exhaust air, which resulted in 20 to $26 \%$ energy savings. The second mode 1s 100\% recirculation of alr through the dryer and a heat exchanger and condensation of water from this air in the heat exchanger by using indoor alr. as a heat sink. This resulted in $100 \%$ heat recovery (1.e., all heat was rejected to indoors) but the energy consumption of the dryer was increased by up to $6 \%$. To maximize energy savings, a clothes dryer with a heat exchanger can be equipped to operate in the preheating mode in the summer and in the recirculation/condensation mode in the winter. The last measure investigated recirculation, through a heat pump (1.e., dehumidifier), also resulted in a $100 \%$ heat recovery and, in addition, up to a $33 \%$ reduction in dryer energy consumption, but this technique also ylelded long drying times.

\section{INTRODUCTION}

Approximately $9 \%$ of the primary energy used in the household sector is consumed by the laundry process and $30 \%$ of this is used in the drying process. The number of clothes dryers in 1978 was 45 million and the ratio of electr1cal clothes dryers to gas-fired clothes dryers was about 2.5 to 1 ( 1 ). Fleld studies on residential electric clothes drying were performed by Pacific Gas and Electric Company (PG\&E) (2) and Oklahoma Gas and Electrlc Company (OG\&E) (3) In 1965 and 1971, respectively. The PGSE survey indicated an annual energy consumption of $1,400 \mathrm{kWh}$ for an average family size of 4.5 people. The OG\&E survey indicated an energy demand of $1,320 \mathrm{kWh} /$ year for an average famfly of 4.8 people. If the energy consumption per load $1 \mathrm{~s} 3.0 \mathrm{kWh}$, there will be approximately 450 drying loads per year, on the average. At a typical electricity price of $\$ 0.075 / \mathrm{kWh}$, the cost for operating a domestic electric clothes dryer would be around $\$ 100$ a year.

Several measures have been undertaken by manufacturers to reduce the energy consumption of clothes dryers. In many of the dryers marketed in Europe, the direction of rotation of the drum reverses periodically throughout the drying cycle to prevent clothes from rolling up into a configuration that is difficult to dry. Also available in Europe are clothes dryers that recirculate the exhaust afr through an alr-to-air heat exchanger (where water is removed by condensation using the Indoor air as a heat sink). An advantage of these units is that no exhaust to outdoors is needed. However, if the clothes dryer is operated in a small room, the room alr temperature can rise substantially 
during operation which results in a decrease in the condensation (dry ing) rate. An inexpensive energy saving measure is to vent the exhaust alr to Indoors during the winter and a variety of manufacturers market valve systems for this purpose. This technique may be sultable in some situations, but the latent heat in the vented air is not recovered unless molsture condenses on indoor surfaces. Excessive condensation of molsture and high humidity may result especially in air-tight residences. In addition, if a gas-fired dryer Is vented to Indoors, high indoor concentrations of potentially harmful combustion products (e.g., nitrogen dioxide and carbon monoxide) may result. One other category of energy saving measures is to modify the consumers' behaviors. The high average number of drying loads per year (518) reported in the 1971 study by OGSE suggests that only a small amount of clothes are dried per load. Less frequent drying of larger loads could save significant energy and some homeowners may have already modifled their behavior in this manner.

In the remalnder of this report, analytical and experimental analyses of various energy saving measures are presented. More detalled information is ava11able in a Lawrence Berkeley Laboratory Report (4).

\section{ANAL YTICAL DESCRIPTION OF THE DRYING PROCESS}

The following simple balances refer to the schematic of an electrically heated clothes dryer in Figure 1. We assume that the sensible heat change of the clothes, the mechanical power Input, and the heat transfer to the surroundings are negligible. A mass balance for the afr and water vapor ylelds

$$
\dot{\mathrm{m}}_{\mathrm{afr}}\left(1+\mathrm{x}_{\infty}\right)+\dot{\mathrm{m}}_{\mathrm{H}_{2} \mathrm{O}}=\dot{\mathrm{m}}_{\mathrm{a} 1 \mathrm{r}}\left(1+\mathrm{x}_{\text {out }}\right) \text {. }
$$

An energy balance for alr passing the heating element gives

$$
\dot{\mathrm{m}}_{\text {air }} \mathrm{h}_{\infty}+\mathrm{P}=\dot{\mathrm{m}}_{\mathrm{a1r}} \mathrm{h}_{1 \mathrm{n}},
$$

and an energy balance for the atr passing through the dryer drum ylelds

$$
\dot{\mathrm{m}}_{\mathrm{a1r}} \mathrm{h}_{\text {in }}+\dot{\mathrm{m}}_{\mathrm{H}_{2} \mathrm{O}} \mathrm{h}_{\mathrm{H}_{2} \mathrm{O}}=\dot{\mathrm{m}}_{\mathrm{a1r}} \mathrm{h}_{\text {out }}+\dot{\mathrm{Q}}_{\text {evap. }} \cdot
$$

\section{DESCRIPTION OF ENERGY SAVING TECHNIQUES}

Reduced A1r Flow Rate

The drying process in a clothes dryer involves forced convection heat transfer and mass transfer with a phase change. Water is transported from the Inside of the wet clothes to their surface by caplllary action and diffusion and then into the surrounding hot a1r. The alr removes moisture through convection to the exhaust condult and provides the heat for evaporation. The rationale behind reducing the air flow rate is to manipulate the kinetics of the drying process so that the increase in evaporating rate, due to a higher alr temperature, ylelds a better energy efficlency despite the reduced convection. Also, since the fresh alr is generally drawn from indoors and the exhaust air is vented to outdoors, reduced alr flow rate results in a smaller draft in the bullding and decreased space heating or cooling loads; however, the savings due to a reduced draft are small (4). 
Recirculation of Exhaust Air

An easy and Inexpensive way to recover exhaust heat is to recirculate a portion of the exhaust air back into the clothes dryer. This procedure increases the average operating temperature and absolute humfdity; two effects which counteract each other (1.e.,the evaporation rate decreases with the increase of humidity but increases with an increase in temperature). To recirculate exhaust alr, modifications to the ductwork are required and more efficient. lint filters have to be installed to prevent lint accumulation and subsequent combustion. Current safety codes in some areas do not permit recirculation.

\section{Heat Recovery, Utilizing an Air-to-A1r Heat Exchanger}

Preheating Mode: One technique to save energy when using an alr-to-a1r heat exchanger is to preheat the inlet air with the exhaust a1r. To overcome the additional resistance to alrflow, an additional or stronger blower is required. Condensation and, thus, latent heat recovery will occur under some operating conditions and the inlet afr can be drawn from outdoors, thus decreasing the draft in the bullding.

The rate of heat transfer in the heat exchanger is

$$
\dot{\mathrm{Q}}=\epsilon \mathrm{C}_{\mathrm{min}}\left(\mathrm{T}_{\mathrm{HS}}-\mathrm{T}_{\mathrm{CS}}\right)
$$

where $C_{m i n}$ is the smaller of the heat capacities of the two airstreams passing through the heat exchanger, and 6 is the temperature effectiveness of the heat exchanger. Since the hot air stream exiting the dryer contains more moisture, which can condense, the cold alrstream will have a lower heat capacity; thus, $C_{m i n}=C_{c}=\dot{m}_{c} C_{p_{c}}$ and $1 \mathrm{n}$ the case of no condensation

$$
\dot{Q}=\epsilon C_{c}\left(T_{H S}-T_{C S}\right)=C_{c}\left(T_{C R}-T_{C S}\right)=C_{h}\left(T_{H S}-T_{H R}\right) \text {. }
$$

For the case where the drying time is unchanged from that in the baseline operating mode (1.e., the same inlet temperature), a new value for the heating element power can be obtalned from the equation,

$$
P=\dot{a}_{a 1 r}\left(C_{P_{a 1 r}}+x_{\infty} C_{P_{H_{2} O}}\right)\left(T_{1 n}-T_{C R}\right)
$$

where $\mathrm{T}_{C R}$ is calculated from equation (5) for a given temperature effectiveness. Assuming typical operating conditions, energy savings of $30 \%$ are predicted.

The savings from using the heat exchanger will be approximately $\$ 30$ per year. The costs for the heat recovery equipment is estimated to be $\$ 100$ if the product is mass produced. This includes: a heat exchanger core, one additional blower, additional ductwork, a more efficlent lint filter (1.e. a fine nylon mesh), and improved seals around drying chamber and door. With a real discount rate of $6 \%$, the simple payback time will be approximately 4 years.

Recirculation/Condensation Mode: A second arrangement to recover heat with an a1r-to-a1r heat exchanger is a system where $100 \%$ of the atr is recirculated through the dryer and the heat exchanger, and a second open-loop alrstream recovers sensible and latent heat by cooling the dryer air and condensing the 
moisture contained in $1 t$. Room air is used for the second a1rstream and the recovered heat'is useful in the winter as space heat. No vent to outdoors is required, all exhaust heat is recovered, and no molsture in the form of vapor is added to indoors. The heat removed from the hot air is approximately

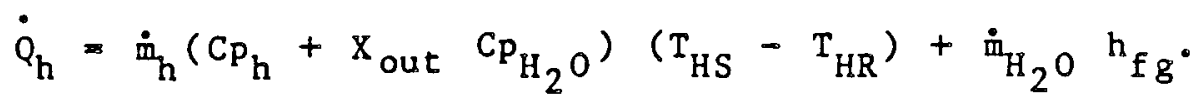

With negligible heat transfer through the case of the heat exchanger

$$
\dot{Q}_{h}=\dot{Q}_{c}=C_{c}\left(T_{C R}-T_{C S}\right)=\epsilon C_{m 1 n}\left(T_{H S}-T_{C S}\right) \text {. }
$$

The two heat recovery modes can be incorporated into a clothes dryer equipped with an alr-to-air heat exchanger and a summer/winter switch (Figure 2). The preheating mode is employed in the summer and the recirculation/condensation mode in the winter.

Recirculation With Condensation, Ut1lizing a Heat Pump

Another method to recover both sensible and latent heat is rectrculation of all the warm air in a closed loop through the dryer and a heat pump (Figure 3). No electric heating element is needed. The exhaust air from the dryer passes through the evaporator coll of the heat pump where 1 cools to below its dewpoint temperature, senstble and latent heat are extracted, and molsture is removed in the form of condensate. The heat is transferred back to the less-molst alrstream at a higher temperature in the condenser coll. One problem is that the maximum condenser temperature of existing heat pumps is too low for this application, thus, long drying times result because the compressor cycles on and off due to a high temperature safety control. If higher condenser temperatures around $80^{\circ} \mathrm{C}$ are achlevable without too low of a coefflclent of performance (take $C O P=2.5$ ), a heat pump with a capacity of around $3 \mathrm{~kW}(10,000 \mathrm{Btu} / \mathrm{h})$ could dry a standard load of clothes in 60 minutes. The reduction in dryer energy consumption would be approximately $60 \%$ and, in add1tion, no heat need be vented to outdoors. However, equipment costs, and malntenance and rellabllity considerations may limit this approach.

\section{EXPERIMENTAL STUDY}

The clothes dryer used during tests is a typical model with a power rating of $5400 \mathrm{~W}$ at $240 \mathrm{~V}$. The heating element is rated at $5000 \mathrm{~W}$, the electric motor is rated at $190 \mathrm{~W}(1 / 4 \mathrm{hp})$ output, and the afr flow rate $1 \mathrm{~s}$ given as $82 \mathrm{l} / \mathrm{s}$ $(173 \mathrm{cfm})$. The drum volume is $1631\left(5.75 \mathrm{ft}^{3}\right)$.

The test procedure consisted of measuring total energy consumption, electric heater energy and power, amount of evaporated water, inlet and outlet temperatures, and humlditles, temperature of the hot air after the heating element, air flow rates, and the drying cycle time lncluding heating time and cool down time. The dryling cycle was terminated manually. The evaporation rate was obtained by calculating the ratio of the amount of evaporated water (determined gravimetrically) to the overall drying time. Tests were conducted with a standard load of clothes containing $50 \%$ synthetic and $50 \%$ cotton fibers that weighed $3.18 \mathrm{~kg}(7 \mathrm{lb})$ when dry. They were wetted to a molsture content of $70 \%$ of the dry welght prior to each test. During the drying cycle, the moisture was reduced to approximately $3-5 \%$ of the bone-dry welght (1). During all 
tests a plastic sheet envelope was attached around the dryer housing to simulate tighter seāls at dryer drum and door and a fine nylon mesh filter was installed in addition to the standard lint filter.

RESULTS

Table 1 describes the various tests and compares the energy requirements and the drying times of different energy saving measures. Figure 4 relates graphlcally the energy consumed during the various test modes.

\section{Baseline Experiments}

The baseline tests slmulated operation in both the heated and unheated sections of a house and included tests with reduced heater power. The alr flow rate was approximately $571 / \mathrm{s}$ (120 cfm) which 1s significantly less than the $82 \mathrm{l} / \mathrm{s}$ (173 cfm) reported by the manufacturer despite the fact that the test system was not substantially more restrictive to flow than a typical installation. The total drying time was approximately $40 \mathrm{~min}$ for the tests with $230 \mathrm{~V}$ at the heater ( $P_{\text {heater }}=4.55 \mathrm{~kW}$, amblent temperature $T_{\infty}=20{ }^{\circ} \mathrm{C}$ ), which included a 2 min cool down time, (1.e., the cool down time was the period of time before termination of the cycle, during which the heater was off). The tests with a lower inlet temperature $\left(T_{\infty}=10^{\circ} \mathrm{C}\right) ;$ simulating dryer operation in the unheated section of. the house, lasted approximately $45 \mathrm{~min}$ and consumed about 13\% more electricity. For tests with a reduced heater 1nput (190 to $200 \mathrm{~V}$, $P_{\text {heater }}=3.1$ to $3.45 \mathrm{~kW}$ ), drying times increased to $52-60$ min with insignificant energy savings.

Experiments With Reduced Alr Flow Rate

In tests with reduced air flow rates and electric heater inputs, drying times were 51-59 min compared to $40 \mathrm{mln}$ for the baseline. Energy savings of approximately 87 were achleved. Approximately $5 \%$ energy savings occurred when the afr flow rate was reduced from $571 / \mathrm{s}$ (120 cfm) to approximately $391 / \mathrm{s}$ (83 $c f m$ ) and the heater power was unchanged.

\section{Recirculation Experiments}

For tests with recirculation, the voltage at the heating element was maintalned at $230 \mathrm{~V}$, and the alr flow rate through the drying chamber was approximately $57 \mathrm{l} / \mathrm{s}$ (120 cfm). The recirculation ratio, defined as the amount of recirculated air divided by the total air flow rate, was 49 to $72 \%$. Due to the use of a second blower upstream of the dryer, a slight pressurization of the drying chamber resulted. A mass balance calculation, indicated that approximately $8 z$ of the evaporated molsture had leaked into the surrounding alrspace.

The drying time for these tests was $43 \pm 1.5 \mathrm{~min}$, which included a cool down time of $5 \mathrm{~min}$. This drying time is not significantly greater than the drying time for the baseline tests. Energy savings were 10.4 to $18.5 \%$ depending on the recirculation ratio. The optimum recirculation ratio, considering drying time and operating temperatures, was around $67 \%$.

The cost to retrofit for recirculation a residential clothes dryer with an accessible air inlet is estimated to be about $\$ 30$ if the labor is performed by the homeowner. (Only some ductwork and an improved lint filter are required.) 
The simple payback time, with a real discount rate of $6 \%$ and yearly energy savings of $\$ 18$, is a lictle less than two years.

Hear Recovery Experiments

The counterflow heat exchanger (5) used in these tests has a heat transfer area of $10.7 \mathrm{~m}^{2}\left(115 \mathrm{ft}^{2}\right)$, an effectiveness of about $70 \%$, and a pressure drop of approximately $65 \mathrm{~Pa}\left(0.26^{\prime \prime} \mathrm{H}_{2} \mathrm{O}\right)$ at a flow rate of $57 \mathrm{l} / \mathrm{s}(120 \mathrm{cfm})$. An additional fan upstream of the heat exchanger provided equal flow rates at the inlet and outlet of the dryer (1.e., minimized leakage at the dryer drum).

Preheating Mode: For tests in the preheating mode, fresh air with a temperature of approximately $10^{\circ} \mathrm{C}$ was preheated with the exhaust air. The voltage at the electric heater was $230 \mathrm{~V}$, and the alr flow rate was approximately $551 / \mathrm{s}$ $(116 \mathrm{cfm})$. The drying time was 39 to $40 \mathrm{~min}$ lncluding a 4 to $5 \mathrm{~min}$ cool down t1me. The energy savings when comparing with baseline tests with $\mathrm{T}=10{ }^{\circ} \mathrm{C}$ were about $26 \%$. The heat exchanger effectiveness was approximately $60 \%$, which is less than indicated previously ( 5 ).

Recirculation/Condensation Mode: For tests in the recirculation / condensation mode, the heater voltage was 190 to $230 \mathrm{~V}$, the alr flow rate through the dryer and heat exchanger was approximately $571 / \mathrm{s}(120 \mathrm{cfm})$ and the flow rate of the of the alr that passed in an open loop through the heat exchanger was approximately $601 / \mathrm{s}(126 \mathrm{cfm})$. The drying time varied from 60.5 to $65.0 \mathrm{~min}$ and the energy consumption was 1.4 to $6.4 \%$ higher than the baseline energy consumption, depending on the electric heater power. Approximately $25 \%$ of the evaporated water escaped to the surroundings due to the fact that the drying chamber was slightly pressurized. The heat exchanger effectiveness ranged from 70 to $80 \%$ - higher than in the preheating mode due to increased latent heat recovery. The indoor alr that was used as a heat sink was returned back to Indoors as dry warm air at a temperature of 45 to $49{ }^{\circ} \mathrm{C}$.

Based upon the results, a brief analysis of the economics of a clothes dryer equipped with an alr-to-air heat exchanger and a summer/winter switch (preheating mode in the summer and recirculation/condensation mode in the winter) is presented. We assume, the clothes dryer is located in an electrically heated house, the heating season lasts 5 months, and heat losses from the clothes dryer housing to the surroundings are negliglble. Furthermore, the increase in energy consumption during the recirculation/condensation mode is assumed negligible. The additional cost is estimated to be $\$ 100$ if the system is mass produced. With $25 \%$ heat recovery in the summer and $100 \%$ heat recovery In the winter, the savings will be approximately $\$ 56 /$ year. Assuming a real discount rate of 67 , the simple payback time will be approximately 2 years.

Experiments w1th a Heat Pump

The heat pump used for the experiments is a residential dehumidifier with a rated capacity of $16.6 \mathrm{l} /$ day ( 35 pints/day) at standard test conditions $\left(T_{\infty}\right.$ $\left.=800^{\circ}, \mathrm{RH}_{\infty}=60 \%\right)$. This rated capacity corresponds to a refrigeration load of approximately $1.9 \mathrm{~kW}(6500 \mathrm{Btu} / \mathrm{h})$. The refrigerant used is $\mathrm{R} 500$.

Four tests were performed, one with the dehumidifier alone and three with a dehumidfier and an alr-to-air heat exchanger in series. The heat exchanger was posftioned upstream of the dehumidifier and its function was to remove 
part of the sensible heat contalned in the exhaust air. The average power Input of the coüpressor was 650 to $850 \mathrm{~W}$, the flow rate through the dryer was about $61 \mathrm{l} / \mathrm{s}(130 \mathrm{cfm})$ for the tests with a heat exchanger and $85 \mathrm{l} / \mathrm{s}$ ( 180 cfm) when the heat exchanger was not used. The flow rate of the cooling a1r through the heat exchanger ranged from 17 to $531 / \mathrm{s}$ (36 to $113 \mathrm{cfm}$ ). In the test without a heat exchanger, the compressor cycled on and of $f$ due to thermal overloading, and the drying time was $150 \mathrm{~min}$. For the other tests, the flow rate of the cooling alr was adjusted so that no or very little cycling occurred which reduced the drylng time to 145 to $120 \mathrm{~min}$. The test with no heat exchanger consumed about $33 \%$ less energy than the baseline, although it lasted approximately 3.75 times as long. With the additional heat exchanger and a low flow rate of cooling air, energy savings were about $29 \%$ and the drying time was 3 times as long as for the baseline. These tests indicate a significant potential for energy savings, however, the dehumidiffer would have to be redesigned so that it will operate with higher condenser temperatures.

\section{SUMMARY}

The four basic energy saving measures that were studied experimentally are: (1) reduced alr flow rate; (2) recirculation of exhaust air; (3) heat recovery, utllizing an afr-to-atr heat exchanger; and (4) rectrculation with condensation, utilizing a heat pump.

Baseline tests 1ndicated that the actual air flow rate through the dryer was smaller than reported by the manufacturer. About half of the heat contained in the exhaust alr appeared as senstble heat. Approximately $8 \%$ energy savings were achleved by reducling the alr flow rate and heater power.

Recirculation of exhaust afr resulted in a 10-18\% decrease in energy consumption, depending on the recirculation ratio. The optimal recirculation ratio was around $67 \%$. The costs to retrofit for recirculation are low and payback times can be as short as two years if the labor is performed by the homeowner. This energy saving measure could also be incorporated into new equipment by the manufacturers.

A 267 reduction in energy consumption was achieved with heat recovery, utilizing an alr-to-air heat exchanger in the preheating mode. High equipment costs (approximately $\$ 100$ ) yleld an estimated payback time of four years for this energy saving measure. However, $100 z$ heat recovery can be achieved by using an a1r-to-air heat exchanger, when the exhaust air 1s $100 \%$ recirculated and the molsture condensed, using indoor air as a heat sink. The drying times in this mode were approximately $50 \%$ higher than the baseline drying times. For a clothes dryer equipped with an air-to-air heat exchanger and designed to operate in the preheating mode in the summer and the recirculation/condensation mode in the winter, the estimated payback time is approximately 2 years in an electrically heated house.

The last experiments were performed using a heat pump. A residential dehumidifler was coupled to a clothes dryer and this integration resulted again in a closed system with $100 \%$ heat recovery and a $33 \%$ reduction in dryer energy consumption. However, the drying time is unacceptably long with currently available heat pumps. 
Summarizing, 1t_can be sald that significant energy savings could result from the various energy saving measures investigated and several of the measures may be cost effective. However, in addition to further laboratory experiments, a better understanding of the cost, marketability, rellablilty and consumer acceptance of various measures is destrable.

\section{ACKNOWLEDGEMENTS}

This work was supported by the Assistant Secretary for Conservation and Renewable Energy, Offlce of Bullding Energy Research and Development, Bullding Systems Division of the U.S. Department of Energy under Contract No. DE-AC0376 SF00098.

\section{NOME NCLATURE}


\section{Subscripts}

\begin{tabular}{lll}
\hline$C R=$ cold return & $H R=$ hot return & In $=$ inlet \\
$C S=$ cold supply & $H S=$ hot supply & out $=$ outlet \\
$C=$ cold & $h=$ hot & $\infty=$ amblent space
\end{tabular}

\section{REFERENCES}

1. Consumer Products Efficlency Standards, Engl neering Analysis Document, U.S. Department of Energy, DOE/CE-0030, March 1982.

2. Res1dential Electric Laundry Dryer Load Research Project, (Pac1fic Gas and Electric Company, San Francisco, California), December 1965.

3. Electric Clothes Dryer Energy Consumption, Fleld Study, Oklahoma Gas and Electric, 1971 .

4. D. Hekmat and W.J. F1sk, "Improving the Energy Effictency of Residential Clothes Dryers," Lawrence Berkeley Laboratory Report, LBL-16813, Berkeley, Callfornia, 94720, July 1983.

5. W.J. Fisk, G.D. Roseme, and C.D. Hollowe11, "Performance of Residential A1r-to-A1r Heat Exchangers: Test Methods and Results," Lawrence Berkeley Laboratory, Report LBL-11793, Berkeley, Callfornla 94720, September 1980. 
Table 1. Comparison of Test Conditions, Energy Savings, and Drying Times

\begin{tabular}{|c|c|c|c|c|}
\hline $\begin{array}{l}\text { Tese Mode } \\
\text { (Number of Iests) }\end{array}$ & Tese Condletone & $\begin{array}{l}\text { Speciftc Energy Consumption } \\
\qquad\left(\mathrm{kWh} / \mathrm{kgH}_{2} \mathrm{O}^{\mathrm{O}}\right)\end{array}$ & $\begin{array}{l}\text { Energy Savings } \\
\text { (z) }\end{array}$ & $\begin{array}{l}\text { Drylng Tioe } \\
\quad(\pi 1 n)\end{array}$ \\
\hline $\begin{array}{l}\text { Baseline } 1 \\
\text { (5 ceoce) }\end{array}$ & 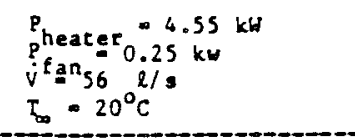 & 1.444 & - & 40 \\
\hline $\begin{array}{l}\text { Baseline } 2 \\
(2 \text { teats) }\end{array}$ & $\begin{array}{l}\text { at above except } \\
T_{0}=10^{\circ} \mathrm{C}\end{array}$ & 1.628 & -12.7 & 45 \\
\hline $\begin{array}{l}\text { Baseline } 3 \\
(3 \text { teate) }\end{array}$ & 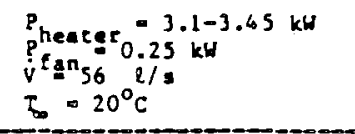 & 2.431 & 0.9 & $52-60$ \\
\hline $\begin{array}{l}\text { Reduced Alr Flow } \\
\text { Rate d Heacer Input } \\
\text { (5 tests) }\end{array}$ &  & 1.324 & 8.3 & $51-59$ \\
\hline $\begin{array}{l}\text { Rec1zculacton } \\
\text { ( } 5 \text { tenta) }\end{array}$ & 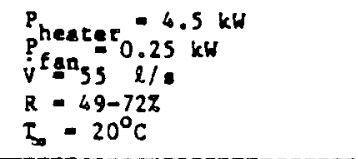 & $\begin{array}{c}1.227 \\
(1.296-1.177)\end{array}$ & $(10.4-18.5)$ & $\begin{array}{l}43 \\
43\end{array}$ \\
\hline $\begin{array}{l}\mathrm{HX} \text { - Prehaec } \\
(4 \text { cests })\end{array}$ & 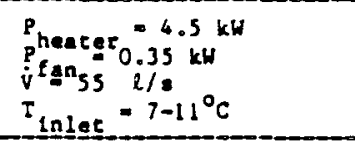 & 1.197 & $26.5^{* \pi}$ & 39 \\
\hline $\begin{array}{l}\text { HX - Rec1 rculation } 1 \\
(4 \text { teots) }\end{array}$ & 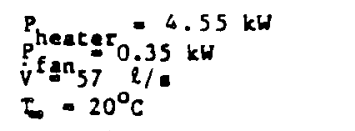 & 1.537 & $-6.4^{\star \star * \star}$ & 60.5 \\
\hline $\begin{array}{l}\text { HX - Recirculation } 2 \\
(3 \text { cests) }\end{array}$ &  & 1.464 & $-1.4 \cdots *$ & 63 \\
\hline $\begin{array}{l}\text { Dehualditier } \\
(1 \operatorname{ces})\end{array}$ & $\begin{array}{l}P \text { coapg }=0.837 \mathrm{kH} \\
P_{t \mathrm{gn}} 0.3 \mathrm{kH} \\
\tau=20^{\circ} \mathrm{c}\end{array}$ & 0.970 & $32.8^{* \star \hbar n}$ & 150 \\
\hline Dehualdiffer / fx & 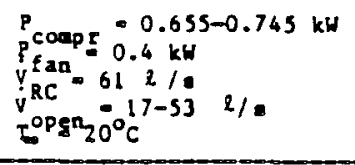 & $1.024-1.215$ & $15.9-29.1^{-k \star \star}$ & $120-145$ \\
\hline
\end{tabular}

- $\mathrm{HX}$ = hear exchanger.

- Compared ro deseline 2. Energy sevinge are eaclanced to be $20 z$ for $\tau_{0}-20^{\circ} \mathrm{C}$.

*t* All energy coneured by the dryer can be added to tha indoor alr co reduce heacting laeda. 


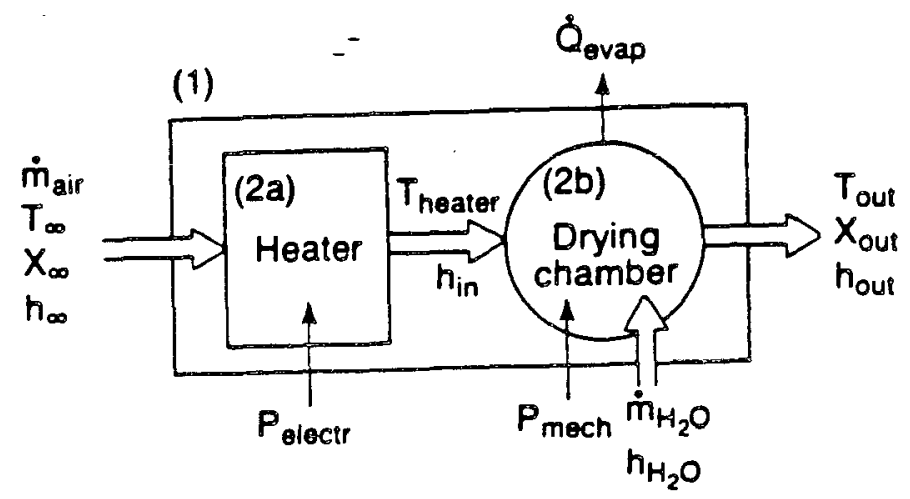

Figure 1 (left)- Schematic diagram of clothes dryer.

XBL 837.2791

Figure 2- Schematic diagram of clothes dryer with an air-to-air heat exchanger and summer/winter switch. The preheating mode is employed in the sumer and the recirculation/condensation mode in the winter.

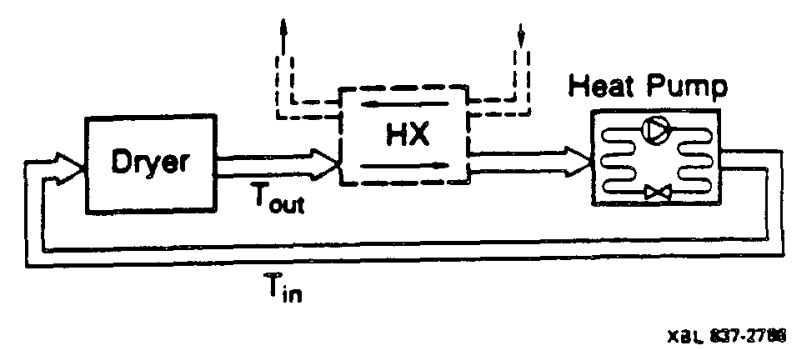

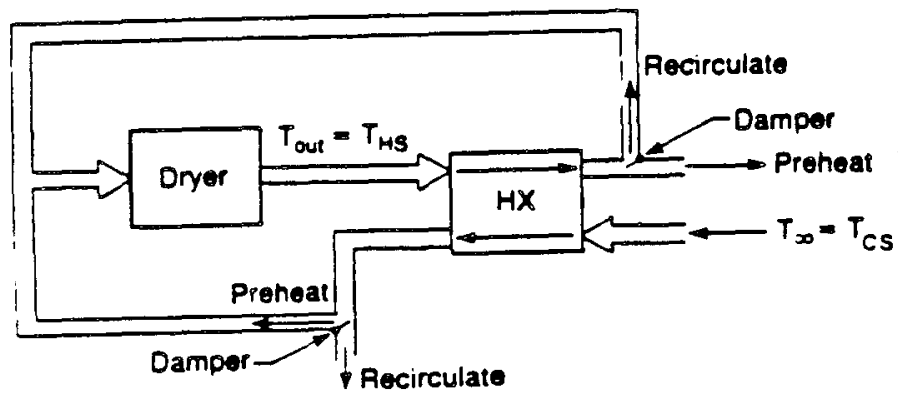

Xอ4 97-27eaA

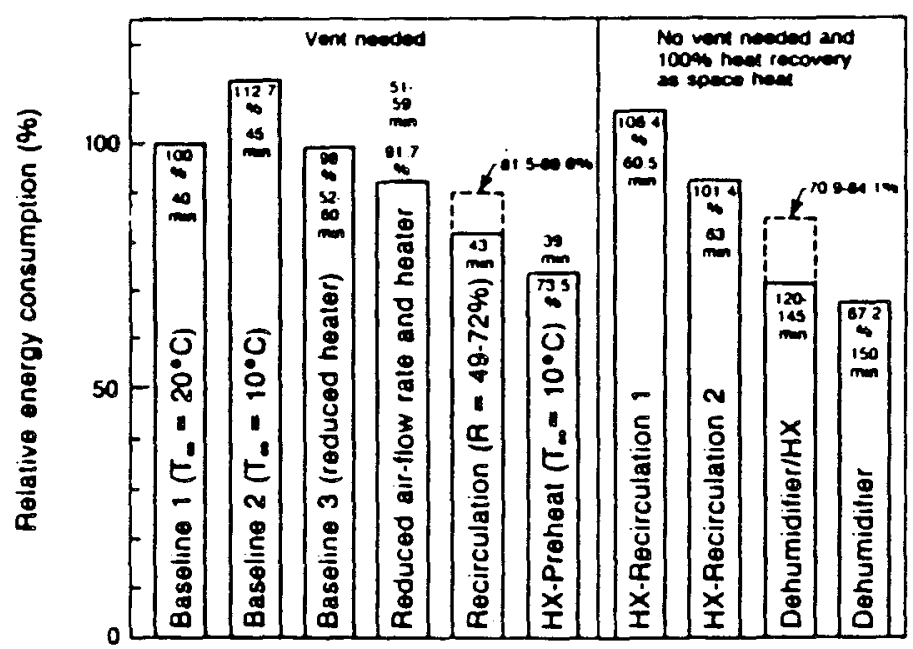

Figure 3 (above)Schematic diagram of a clothes dryer with a heat pump and an optional air-to-air heat exchanger.
Figure 4-Comparison of experimentally determined energy requirements and drying times. 